\title{
Water use on nonirrigated pasture-based dairy farms: Combining detailed monitoring and modeling to set benchmarks
}

\author{
C. D. Higham, ${ }^{*} \dagger^{1}$ D. Horne, $\dagger$ R. Singh, $\dagger$ B. Kuhn-Sherlock, ${ }^{*}$ and M. R. Scarsbrook ${ }^{*}$ \\ *DairyNZ Limited, Private Bag 3221, Hamilton 3240, New Zealand \\ †Massey University, Institute of Agriculture and Environment, Private Bag 11222, Palmerston North 4474, New Zealand
}

\begin{abstract}
Water use in intensively managed, confinement dairy systems has been widely studied, but few reports exist regarding water use on pasture-based dairy farms. The objective of this study was to quantify the seasonal pattern of water use to develop a prediction model of water use for pasture-based dairy farms. Stock drinking, milking parlor, and total water use was measured on 35 pasture-based, seasonal calving dairy farms in New Zealand over 2 yr. Average stock drinking water was $60 \mathrm{~L} /$ cow per day, with peak use in summer. We estimated that, on average, $26 \%$ of stock drinking water was lost through leakage from water-distribution systems. Average corrected stock drinking water (equivalent to voluntary water intake) was $36 \mathrm{~L} / \mathrm{cow}$ per day, and peak water consumption was $72 \mathrm{~L} /$ cow per day in summer. Milking parlor water use increased sharply at the start of lactation (July) and plateaued (August) until summer (February), after which it decreased with decreasing milk production. Average milking parlor water use was $58 \mathrm{~L} /$ cow per day (between September and February). Water requirements were affected by parlor type, with rotary milking parlor water use greater than herringbone parlor water use. Regression models were developed to predict stock drinking and milking parlor water use. The models included a range of climate, farm, and milk production variables. The main drivers of stock drinking water use were maximum daily temperature, potential evapotranspiration, radiation, and yield of milk and milk components. The main drivers for milking parlor water use were average per cow milk production and milking frequency. These models of water use are similar to those used in confinement dairy systems, where milk yield is commonly used as a variable. The models presented fit the measured data more accurately than other published models and are easier to use on pasture-based dairy farms, as they do
\end{abstract}

Received August 3, 2016.

Accepted September 12, 2016.

${ }^{1}$ Corresponding author: caleb.higham@dairynz.co.nz not include feed and variables that are difficult to measure on pasture-based farms.

Key words: water use, water efficiency, leakage, milking parlor, pasture systems

\section{INTRODUCTION}

Agriculture is the most significant water user in the world, accounting for an estimated $70 \%$ of global water withdrawals (World Water Assessment Programme, 2009); most of this water is used for irrigation. Agricultural demand for water is expected to grow to meet the $70 \%$ increase in global food production required to feed 9.7 billion people by 2050 (Food and Agriculture Organization, 2009; United Nations, 2015). As a consequence, where freshwater is scarce there will be an increased focus on improving the efficiency of water use (International Water Management Institute, 2007; Wani et al., 2009) and greater regulation of water use on environmental flows and water quality (Scarsbrook and Melland, 2015). Water footprinting methodologies are already being developed to enable water use comparisons between regions to increase the efficiency of water use (Ridoutt and Pfister, 2010; ZonderlandThomassen and Ledgard, 2012).

Total water (TW) use on dairy farms is typically divided into 3 key areas: stock drinking water use (SDW), milking parlor water use (MPW), and irrigation water use. Cow water requirements [voluntary water intake (VWI)] have been benchmarked for confinement systems (Murphy et al., 1983; Meyer et al., 2004; Cardot et al., 2008), but limited information exists on SDW (Jago et al., 2005), MPW (Callinan, 2009; Murphy et al., 2014) and TW in pasture-based systems. Although many models can predict VWI (Castle and Thomas, 1975; Dahlborn et al., 1998; Appuhamy et al., 2014), most have been developed in confinement systems, which are markedly different to seasonal pasture-based systems (Roche et al., 2013). For example, confinement dairy systems have a more consistent quality of feed and DMI, which is easier to monitor and use in the predictive models. In comparison, DM of fresh pasture 
can vary from $<12$ to $>30 \%$ (DairyNZ, 2012) and DMI of pasture is difficult to measure accurately. Consequently, many of these models are not practical for use on pasture-based dairy farms. Furthermore, we could not find any published prediction models for MPW or TW from pasture-based dairy farms, or estimation of water loss from SDW distribution systems on pasturebased farms.

Voluntary water intake models are available and include a range of variables. Commonly used variables used to predict VWI are DMI, DM, milk yield, and temperature (Little and Shaw, 1978; Stockdale and King; 1983, Kume et al., 2010). Other variables used include sodium content (Meyer et al., 2004), BW (Khelil-Arfa et al., 2012), sunshine hours (Cowan et al., 1978), rainfall (Cardot et al., 2008), and Julian day (Holter and Urban, 1992). Some of these variables are available on pasture-based farms or approximated with other measures, whereas others, such as sodium content and DMI, are difficult to measure. The objective of the current study was to quantify the seasonal pattern of water use to set benchmarks and develop prediction models of water use that are applicable to pasturebased dairy farms.

\section{MATERIALS AND METHODS}

Water use was measured on 35 dairy farms in the Waikato region of New Zealand $\left(38^{\circ} \mathrm{S}, 175^{\circ} \mathrm{E}\right)$ between June 2013 and May 2015. Five farms were excluded from the data set due to insufficient or poor-quality data. Of the farm measurements, MPW, SDW, and TW were all recorded on 21 farms, and individual MPW, SDW, or TW was recorded on 10, 2, and 2 farms, respectively. The study sample size increased as water meters and telemetry were being installed and more farms began monitoring; the sample size grew until all 35 farms were supplying data, in total, 44.7 farm-years worth of data were collected. No specific average water-use values for any one day were calculated using data with a sample size less than 5 farms.

All SDW, MPW, TW, and farm total milk production data were converted to units per cow per day to allow comparisons across farms on a per-cow basis (L/ cow per day, $\mathrm{kg}$ of milk fat plus protein, or milk yield/ cow per day). Water use, milk fat plus protein yield, and milk volume were calculated from peak yearly cow numbers for the relevant season.

\section{Farm Description}

All farms were seasonal (spring)-calving dairy farms, and the main characteristics of the case study farms are summarized in Table 1. Farm herd size ranged from 160 to 1,150 cows per farm; 19 farms herringbone milking parlors and 16 had rotary parlors, with the number of bails (stalls) ranging from 16 to 52 and 30 to 60 bails, respectively. Average rainfall for the farms was 1,053 $\mathrm{mm}$ per year. Average yearly maximum and minimum temperatures were 18.8 and $8.6^{\circ} \mathrm{C}$, respectively. Average Priestly-Taylor potential evapotranspiration and solar radiation were $2.49 \mathrm{~mm} / \mathrm{d}$ and $14.6 \mathrm{MJ} / \mathrm{m}^{2}$ per $\mathrm{d}$, respectively. Average milk volume was $4,536 \mathrm{~kg} / \mathrm{cow}$ per annum, and average milk fat plus protein yield was $394 \mathrm{~kg} /$ cow per annum.

\section{Data Collection}

Water use was collected continuously using water meters with a telemetry system. All water-use data were recorded at 15-min intervals, except 3 farms that supplied water-use data with hourly or daily volumes (2 farms measuring MPW; 1 farm measuring TW). The selected farms were categorized by production system type according to the amount of nonpasture feed purchased per cow per annum (Ramsbottom et al., 2015). A system 1 farm is the lowest input production system (pasture-based with no imported feed) and system 5 is the highest input system (25-40\% imported feed).

Daily climate data were sourced for the entire study period. A total of 730 daily records on 24 -h maximum temperature $\left({ }^{\circ} \mathrm{C}\right)$, 24-h minimum temperature $\left({ }^{\circ} \mathrm{C}\right)$, 24-h rainfall $(\mathrm{mm}), 24-\mathrm{h}$ solar radiation $\left(\mathrm{MJ} / \mathrm{m}^{2}\right), 24-\mathrm{h}$ wind run $(\mathrm{km})$, and 24 -h potential evapotranspiration $(\mathrm{mm})$ were obtained from the NIWA Virtual Climate Station Network (Cichota et al., 2008). The Virtual Climate Station Network uses data from weather stations and interpolates it over a 5 by $5 \mathrm{~km}$ grid across New Zealand.

\section{Data Management and Calculations}

Total water use is defined as MPW plus SDW and was measured at the source (abstraction point). Stock drinking water is defined here as the VWI of cows (water drank from a trough as opposed to water ingested in feed or metabolic water) and any water loss that occurs in water-distribution systems on farms (leakage incurred distributing water via pipes and troughs to cows in the paddock).

Water-use data were processed using Hilltop Software (Kmoch et al., 2015), a Microsoft (Redmond, WA) Windows-based database and reporting application suite for hydrology-related time series data. Visual quality checks were performed using the graphing functions of Hilltop Software. Invalid days (i.e., days that had missing data in the 15-min scale caused by recording errors) were removed. Data were excluded 


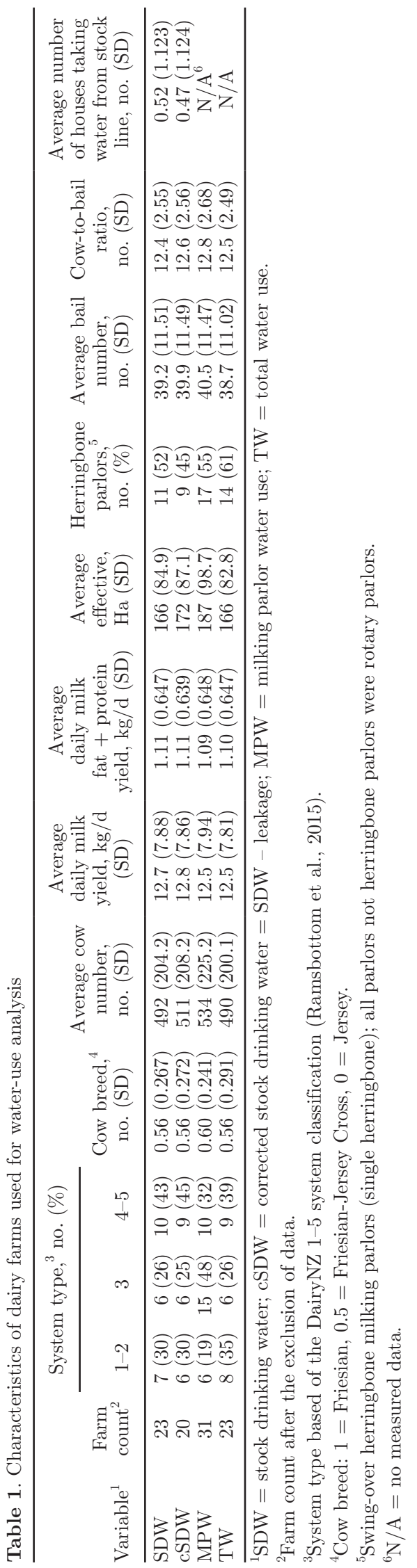

from analyses for the following reasons: the water meter for SDW only covered part of the farm $(\mathrm{n}=2)$; a housing development took unknown amounts of water from the SDW line $(\mathrm{n}=1)$; and water uses could not be distinguished from each other $(n=1)$.

Where TW was measured in conjunction with MPW or SDW, using 2 separate water meters, the unknown MPW $(\mathrm{n}=11)$ or SDW $(\mathrm{n}=1)$ value was calculated using equations [1] or [2], via coding in Hilltop Software:

$$
\mathrm{MPW}=\mathrm{TW}-\mathrm{SDW}
$$

and

$$
\mathrm{SDW}=\mathrm{TW}-\mathrm{MPW} .
$$

All SDW data were exported from Hilltop Software at 15-min intervals to ensure all time stamps were identical for the data set. Milking parlor water use and TW were exported from Hilltop Software at daily intervals. Further data management was carried out in MS Excel (Microsoft Corp.).

During the initial analysis, water leakage from the distribution system was suspected because of large differences in water usage on individual farms in the 15-min water data sets. Therefore, SDW data were analyzed and adjusted (corrected) for loss (i.e., leakage) from the water-distribution system at this time scale using a modification of the minimum night flow leakage estimation method (Tabesh et al., 2009; Cheung et al., 2010). According to this methodology, the average water-use rate between 0000 and $0300 \mathrm{~h}$, defined as average night flow, was subtracted from that day's SDW rate. This method assumes that stock drink negligible quantities during this period (Jago et al., 2005). Average night flow was used over the minimum flow, as water meters pulse at set volumes, typically between 1 to $100 \mathrm{~L}$. Therefore, low leakage rates can have zero pulses in a 15-min period and small leakages would be missed using the minimum night flow.

Program code was written in $\mathrm{R}$ ( $\mathrm{R}$ Core Team, 2015) to automatically identify when leakage events occurred (Supplemental File S1; https://doi.org/10.3168/ jds.2016-11822). The code was written to include the average 15-min flow rate (i.e., leakage) calculated from the 0000 to $0300 \mathrm{~h}$ period, which was subtracted from that day's 15-min stock drinking water data. Leakage was deemed to have ended when 4 out of 5 consecutive values were below 0.75 of the calculated leakage rate or when the end of the day was reached. When leakage was identified, then the previous day's data were checked (working backward through the data). If no correction was found in the previous day (as would be 
the case if a leak began during the day), then the data were corrected. The correction stopped when 4 out of 5 consecutive values were below 0.75 of the calculated leakage rate until the start of the leak was reached. If the day was already found to be corrected, then the script moved onto the next day. Variations in SDW volumes at the 15-min time scale, which did not trigger the end of the correction, can give rise to small negative values once corrected; the script set these to zero.

The adjusted SDW was thereafter termed the corrected stock drinking water (cSDW). Three farms were excluded from having their SDW corrected, as the pump and tank infrastructure prevented the pumping pattern being able to be related to water usage due to water filling storage tanks at night. The data from these farms were used for the SDW calculations, but not the cSDW and were not included in the derivations of water-use models. Leakage rates in parlors were $0.7 \%$ of MPW. As the leakage rate was so low, MPW was used without correction in all analyses.

Water for domestic use was sourced from the stock water distribution line on 11 farms (Table 1). The number of houses on these farms ranged between 1 and 4 . A total water use of 1,500 L/d per house was assumed, based on average water use of $300 \mathrm{~L} / \mathrm{d}$ per person, for a 5 -person household (Ministry of Health, 2006); this domestic water use was subtracted from SDW and cSDW. Total water use on 10 farms did not include domestic water use; however, on 13 farms domestic water use was unable to be separated out from TW. As it was estimated to be less than $5 \%$ of the TW, this was considered a minor issue and the data were used without correction. On 2 farms houses collected rain water for domestic use; they used SDW to fill their tanks for short periods during summer if rainfall was not sufficient for requirements. This was not accounted for, as we were not able to determine accurately whether SDW water was used in this manner.

\section{Statistical Analyses}

We calculated the effects of milking parlor type and season on average water use, and the effect of season on the estimated leakage from SDW. For this purpose, the year was split into 5 seasons, aligning the nonmilking period with the winter season (June and July), early spring (August and September), late spring (October and November), summer (December to February), and autumn (March to May). Analysis was based on a splitplot model, with milking parlor type included in the main plot and season and season-by-parlor type in the subplot. Milking frequency was included as a covariate.

Partial least squares regression modeling was used to evaluate the ability of a combination of different colinear variables to predict SDW, cSDW, MPW, and TW (Wold et al., 2001; Sobek et al., 2005). Potential predictor variables were included as linear and quadratic terms. Initial analyses resulted in greater predictive coefficient of determination values for cSDW when compared with SDW, and, therefore, further modeling was confined to cSDW. The initial partial least squares model included all variables relevant to the water use (Table 2). This was followed by repeated procedures, in which factors of lowest influence (lowest standardized coefficient) were removed one at a time until a model was produced with a combination of good predictive power (i.e., predictive $\mathrm{R}^{2}$ close to that of the initial model) and parsimony; up to 5 models were presented for each water use. Cross-validation was undertaken using a leave-group-out technique with 50 randomly chosen subsets of the data. The predictive ability of the model is calculated leaving all observations in the same subset out at a time and recalculating the model, resulting in 50 recalculated models. Response variables were $\log _{10}$-transformed to achieve homogeneity of variance. Analyses were carried out using SAS 9.3 (SAS Institute Inc., Cary, NC) and Minitab 16.2 (Minitab Inc., State College, PA.

\section{Water-Use Models Comparison and Evaluation}

We compared the VWI models of Castle and Thomas (1975) and Dahlborn et al. (1998; equations [3] and [4], respectively) with cSDW model 3 . These models were chosen because they used DM of pasture in the models, for which we had data, and did not include a DMI variable, for which we did not have data. The DM content of pasture was not measured on individual farms, but weekly DM values, ranging from $15 \%$ in spring to $41 \%$ (monthly average) in summer, were used from a local research farm for the period June 2013 to May 2015 (measured on a Waikato research farm; C. Roach, DairyNZ, Hamilton, New Zealand, personal communication). The resulting models were

$$
\begin{aligned}
\text { VWI model } & =-15.3+2.53 \times \text { milk yield } \\
& +0.45 \times \mathrm{DM} \% \\
\text { VWI model } & =14.3+12.4 \times \text { milk yield } \\
& +0.32 \times \mathrm{DM} \%
\end{aligned}
$$

Models were compared using plots of the predicted versus collected data, the coefficient of determination of the line of best fit, Pearson correlation coefficients, root mean square error, Nash-Sutcliffe efficiency, percentage bias, and root mean square error-to-observations standard deviation ratio (Moriasi et al., 2007). 


\section{RESULTS}

Temporal patterns for average TW, MPW, SDW, and cSDW are presented in Figures 1a, 1b, 1c, and $1 \mathrm{~d}$, respectively, and monthly and seasonal averages are presented in Table 3. All 4 measures of water use show a strong cyclical, seasonal pattern, with relatively high water use in spring and summer. Milking parlor water use increased sharply at the beginning of lactation (winter and early spring) and plateaued until mid lactation (summer). In comparison, SDW requirements were more variable during the same period and peaked in summer.

Total water use, which is a combination of MPW and SDW, increased at the beginning of lactation and was greatest in summer. Annual average SDW (Table 3) was $60 \mathrm{~L} /$ cow per day; it was highest in summer $(78 \mathrm{~L} /$ cow per day) and lowest in winter (31 L/cow per day), with the month of January recording the highest SDW (105 L/cow per day) and June the lowest (15 L/cow per day). We found substantial leakage $(>21 \%)$ from the reticulation systems providing stock drinking water on half the farms $(\mathrm{n}=20)$. Average leakage ranged from 2 to $61 \%$ of SDW on individual farms and was $26 \%$ of SDW (16 L/cow per day; 5,837 L/cow per year); leakage did not vary with season. Annual average cSDW was $35 \mathrm{~L} /$ cow per day; it was highest in summer (51 L/ cow per day) and lowest in winter $(19 \mathrm{~L} /$ cow per day), with the month of January recording the highest cSDW (72 L/cow per day) and June the lowest (4 L/cow per day). Annual average MPW was $50 \mathrm{~L} / \mathrm{cow}$ per day; it was highest in late spring $(64 \mathrm{~L} /$ cow per day) and lowest in winter $(21 \mathrm{~L} / \mathrm{cow}$ per day), with the month of August recording the highest MPW (82 L/cow per day) and June the lowest (9 L/cow per day). Although average MPW use was not significantly affected by milking parlor type (average herringbone and rotary MPW use was $50.7 \pm 5.7$ and $51.9 \pm 6.3 \mathrm{~L} /$ cow per day, respectively; mean $\pm \mathrm{SE}$ ), we noted an interaction between milking parlor type and season. Herringbone MPW requirements were $5.2 \mathrm{~L} /$ cow per day greater $(P<0.001)$ in winter and $2.9 \mathrm{~L} /$ cow per day greater $(P<0.05)$ during early spring, whereas rotary MPW use was greater $(P<0.001)$ in late spring, summer,

Table 2. List of farm variables used for water use modeling

\begin{tabular}{|c|c|}
\hline $\begin{array}{l}\text { Variable } \\
\text { abbreviation }\end{array}$ & Variable description \\
\hline TMax & Maximum daily temperature $\left({ }^{\circ} \mathrm{C}\right)$ \\
\hline TMin & Minimum daily temperature $\left({ }^{\circ} \mathrm{C}\right)$ \\
\hline Rain & Rainfall (mm) \\
\hline Evap & Priestly Taylor potential evapotranspiration ( $\mathrm{mm}$ ) \\
\hline Wind & Wind run $(\mathrm{km})$ \\
\hline Rad & Solar radiation $\left(\mathrm{MJ} / \mathrm{m}^{2}\right)$ \\
\hline Milk Sol & Milk solids (milk fat + milk protein, $\mathrm{kg}$ ) \\
\hline Milk Vol & Milk volume (L) \\
\hline Milking & Number of milkings in a day \\
\hline System & Production system type ( 1 to 5$)$ \\
\hline FeedPad_Yes & Feed pad present \\
\hline YrRound_Yes & Year-round milking \\
\hline Brd & Cow breed $(1=$ Friesian, $0.5=$ Friesian-Jersey cross, $0=$ Jersey $)$ \\
\hline Cow & Number of cows \\
\hline EffArea & Farm effective area \\
\hline Rotary & Milking parlor type (rotary $=1$, herringbone $=0$ ) \\
\hline Bails & Number of bails in the milking parlor \\
\hline CowBail & Number of cows to number of bails ratio \\
\hline Cows/ha & Stocking rate $($ cows/ha) \\
\hline Houses_Yes & If domestic houses are taking from the stock water line $($ Yes $=1$, No $=0)$ \\
\hline HouseNo & Number of domestic houses taking water from the stock water line \\
\hline Weekend & Weekend days $($ Yes $=1$, No $=0)$ \\
\hline ESp & Early spring $($ Yes $=1$, No $=0$ ) \\
\hline LSp & Late spring $($ Yes $=1$, No $=0)$ \\
\hline Sum & Summer $($ Yes $=1$, No $=0)$ \\
\hline Aut & Autumn $($ Yes $=1$, No $=0)$ \\
\hline Recycle_Yes & Recycling cooler water to stock drinking water $($ Yes $=1$, No $=0)$ \\
\hline Recirculate_Yes & Recirculates cooling water into the same tank $($ Yes $=1$, No $=0)$ \\
\hline SnapCh_Yes & The parlor has a snap chiller $($ Yes $=1$, No $=0)$ \\
\hline RRSC_Yes & One of Recycle_Yes, Recirculate_Yes or SnapCh_Yes is true $($ Yes $=1$, No $=0$ ) \\
\hline FY_201314 & June 1, 2013, to May 31, $2014($ Yes $=1$, No = 0) \\
\hline $\mathrm{Sq}$ & Squared \\
\hline
\end{tabular}


and autumn (3.7, 2.6, and $8.0 \mathrm{~L} / \mathrm{cow}$ per day more, respectively). Annual average TW was $113 \mathrm{~L} /$ cow per day; it was highest in summer (147 L/cow per day) and lowest in winter ( $53 \mathrm{~L} /$ cow per day), with the month of January recording the highest TW (187 L/cow per day) and June the lowest (24 L/cow per day).

Partial least squares regression produced predictive models for cSDW (Table 4), MPW (Table 5), and TW (Table 6). The raw coefficients used to predict $\log _{10}$ water use are presented in these tables, rather than the standardized coefficients on which importance was assessed. We produced 4,5 , and 4 models for cSDW, MPW, and TW, respectively, with their predictive powers varying between 0.41 and 0.61 . Whereas the models with a lower number of variables had a lower coefficient of determination, they provide a useful option when data were limited. The water use for cSDW model 3 , MPW model 3, and TW model 3 can be calculated using equations [5], [6], and [7], respectively, followed

a)

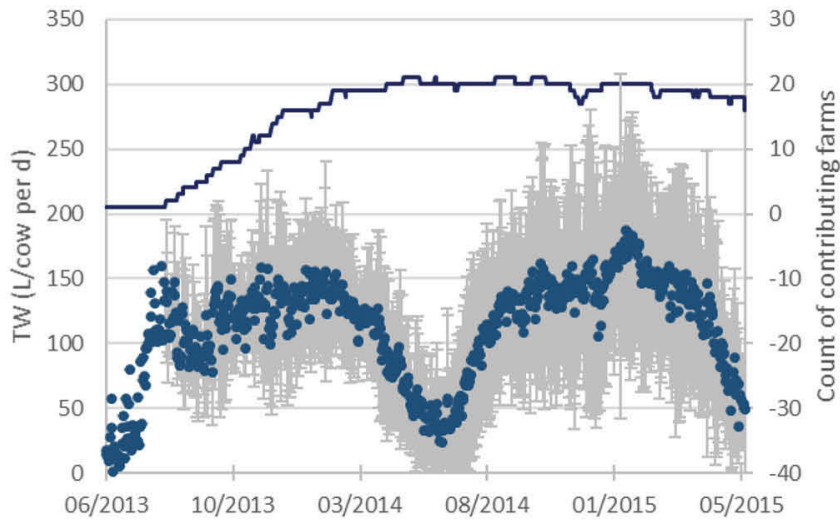

c)

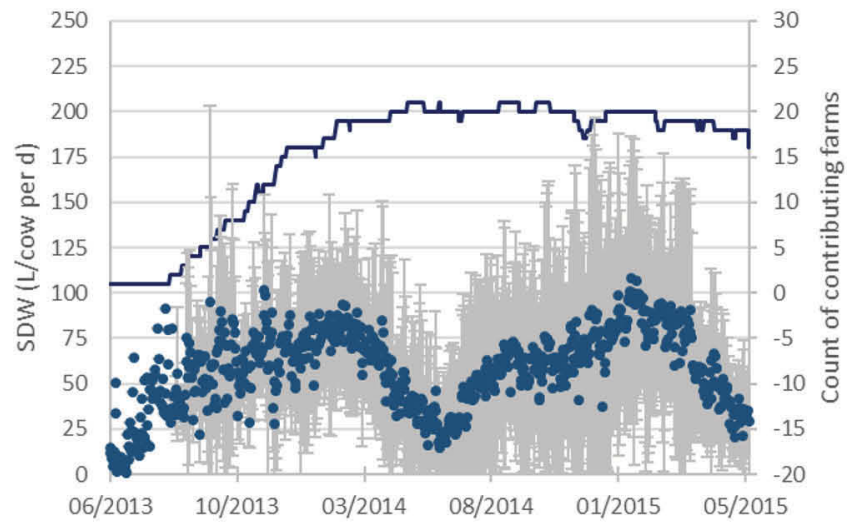

Date by back transformation (abbreviations are defined in Table 2):

$\log \mathrm{CSDW}($ Model 3) $=0.369+0.030 \times$ TMax

$-0.009 \times$ Rain $+0.0001 \times$ Rain $^{2}-0.117 \times$ Evap

$-0.008 \times \mathrm{Evap}^{2}+0.041 \times \mathrm{Rad}+0.261 \times$ MilkSol

$-0.001 \times \mathrm{MilkVol}^{2}-0.322 \times$ Milking

$-0.124 \times$ Milking $^{2}$;

LogMPW $($ Model 3$)=1.168+0.417 \times$ MilkSol

$-0.208 \times$ MilkSol $^{2}+0.026 \times$ MilkVol +0.315

$\times$ Milking $-0.021 \times$ Milking $^{2}-0.301$

$$
\times \text { Brd }-0.029 \times \text { CowBail; }
$$

and

b)

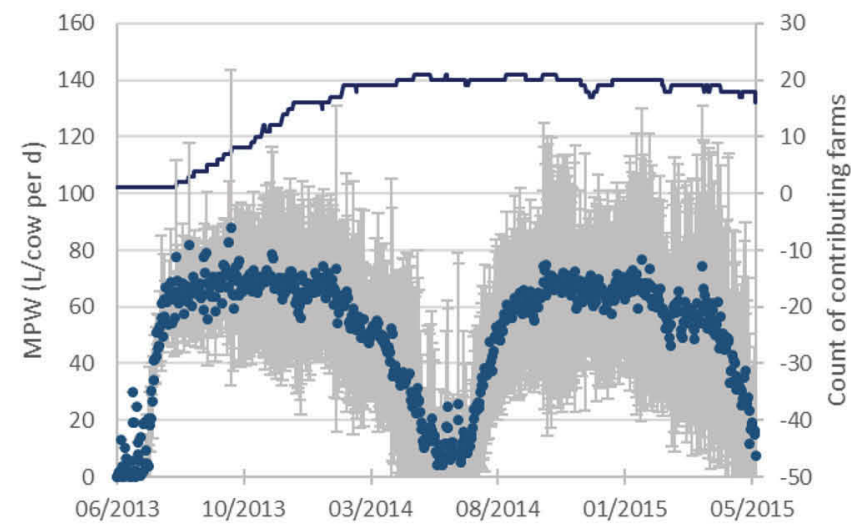

d)

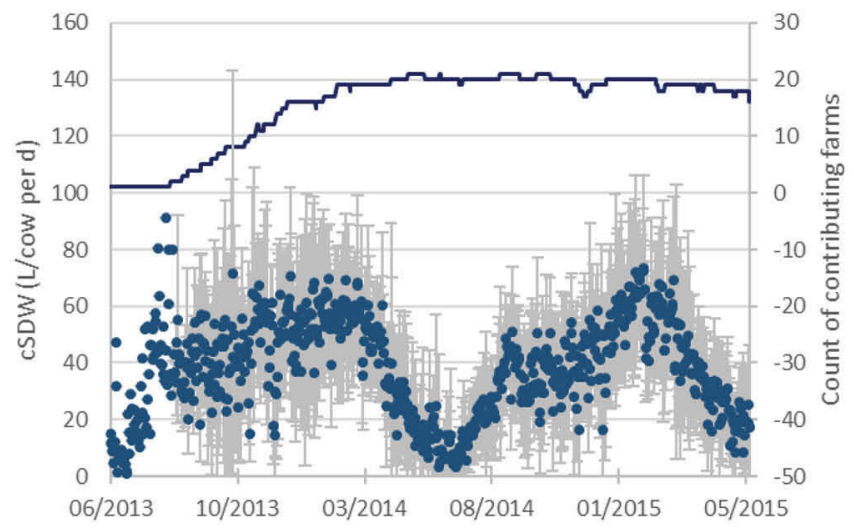

Date

Figure 1. Mean daily water use (e, circles) \pm 1 SD (error bars) and count of farms contributing to the data (solid line, secondary axis) for (a) total water use (TW), (b) milking parlor water use (MPW), (c) stock drinking water (SDW), and (d) corrected stock drinking water (cSDW). Color version available online. 
LogTW $($ Model 3$)=1.104+0.015 \times$ TMax -0.011

$$
\begin{aligned}
& \times \mathrm{Evap}^{2}+0.016 \times \mathrm{Rad}+0.487 \times \text { MilkSol }-0.265 \\
& \times \mathrm{MilkSol}^{2}+0.025 \times \mathrm{MilkVol}+0.051 \times \text { Rotary. }[7]
\end{aligned}
$$

These 3 models were chosen for evaluation because they had a balance between predictive power and number of variables. The variables that were best at predicting cSDW, shown in cSDW model 5 (Table 4), were maximum temperature, potential evapotranspiration, solar radiation, and milk production. The variables that were best at predicting MPW, shown in MPW models 4 and 5 (Table 5), were milk production variables, cow breed, and the cow-to-bail ratio. The variables that were best at predicting TW, shown in TW model 4 (Table 6), were milk production variables.

The cSDW model 3, MPW model 3, and TW model 3 predicted versus observed plot line of best fit gave coefficients of determination of 0.85 (Figure 2a), 0.90 (Figure $2 \mathrm{~b}$ ), and of 0.81 (plot not presented), respectively. Voluntary water intake predictions calculated using the models of Castle and Thomas (1975) and Dahlborn et al. (1998) versus measured cSDW are presented in Figure $2 \mathrm{c}$ and $2 \mathrm{~d}$, with line of best fit coefficients of determination of 0.40 and 0.44 , respectively. Prediction versus observed evaluation of cSDW model 3, MPW model 3, TW model 3, and the predictions of Castle and Thomas (1975) and Dahlborn et al. (1998) are presented in Table 7. Compared with the VWI models of
Castle and Thomas (1975) and Dahlborn et al. (1998), the cSDW model 3 resulted in the best fit for the data.

\section{DISCUSSION}

All measured water uses (SDW, cSDW, MPW, and TW) exhibited a clear seasonal pattern that was aligned with the seasonal calving nature of New Zealand pasture-based dairy systems. Water use in the milking parlor was greatest when milk production was highest, and SDW and TW were greatest during high temperatures in summer. Water use was lowest in winter, when cows were not lactating and temperatures were low. Our study is the first to report this clear cyclical pattern of SDW on pasture-based dairy farms.

The average SDW was $60 \mathrm{~L} /$ cow per day $(21,734 \mathrm{~L} /$ cow per year), and reached a maximum in summer and a minimum in winter. This variability in SDW was associated with both milk production and climate, principally temperature. Substantial leakage ( $>21 \%$ of SDW) was identified on over half of the farms. Leakage rates were highly variable between farms, but we found no difference in leakage between seasons. Although it was impossible to physically check the volume of leakage and, therefore, determine how accurate the correction to SDW was, the stronger correlation between cSDW and climate and milk production variables compared with SDW gives confidence in the validity of the correction.

Table 3. Average monthly stock drinking water (SDW), corrected stock drinking water (cSDW $\left.{ }^{1}\right)$, leakage, milking parlor water use (MPW), and total water use (TW) on pasture-based dairy farms (n)

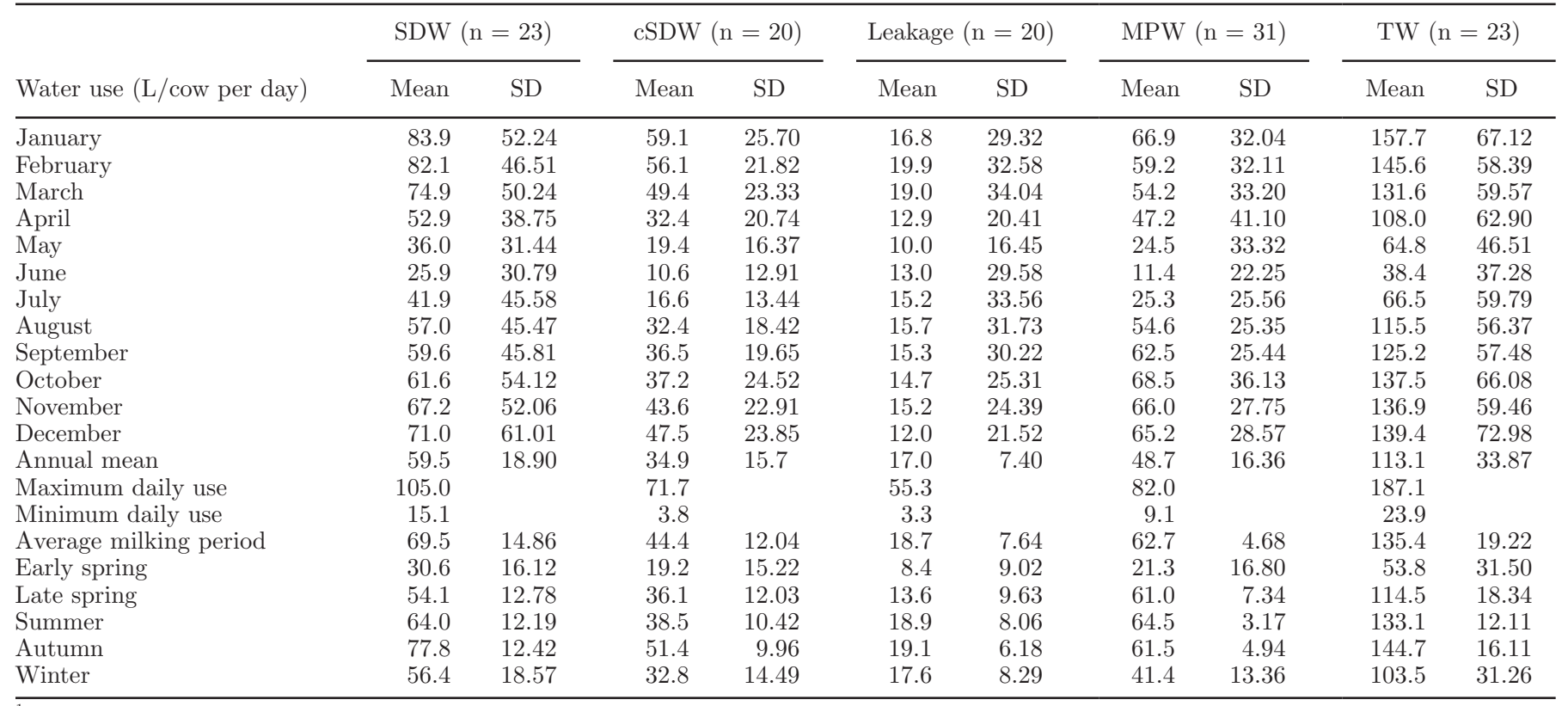

${ }^{1} \mathrm{cSDW}=\mathrm{SDW}-$ leakage. 
Table 4. Partial least squared regression model $^{1}$ equations (raw coefficients) for predicting corrected stock drinking water use $\left(\log _{10} \mathrm{cSDW}\right)$ on pasture-based dairy farms $(\mathrm{n}=22)$

\begin{tabular}{|c|c|c|c|c|c|}
\hline Variable $^{1}$ & Model 1 & Model 2 & Model 3 & Model 4 & Model 5 \\
\hline$\overline{\mathrm{R}^{2}}$ & 0.51 & 0.47 & 0.46 & 0.45 & 0.45 \\
\hline$P$-value & $<0.001$ & $<0.001$ & $<0.001$ & $<0.001$ & $<0.001$ \\
\hline Constant & 0.6516 & 0.3744 & 0.3686 & 0.3596 & 0.4251 \\
\hline TMax & 0.0149 & 0.0253 & 0.0296 & 0.0276 & 0.0246 \\
\hline TMaxSq & 0.0003 & & & & \\
\hline TMin & -0.0125 & & & & \\
\hline TMinSq & 0.0006 & & & & \\
\hline Rain & -0.0098 & -0.0091 & -0.0094 & & \\
\hline RainSq & 0.0002 & 0.0001 & 0.0001 & & \\
\hline Evap & 0.0402 & 0.0343 & -0.1165 & -0.0710 & \\
\hline EvapSq & -0.0088 & -0.0139 & -0.0081 & -0.0146 & -0.0168 \\
\hline Wind & -0.0169 & & & & \\
\hline WindSq & -0.0004 & & & & \\
\hline $\operatorname{Rad}$ & 0.0143 & 0.0175 & 0.0405 & 0.0431 & 0.0318 \\
\hline RadSq & -0.0001 & & & & \\
\hline Milk Sol & 0.1410 & 0.2831 & 0.2609 & 0.3728 & 0.3722 \\
\hline Milk SolSq & -0.0167 & & & & \\
\hline Milk Vol & 0.0042 & & & & \\
\hline Milk VolSq & -0.0004 & -0.0006 & -0.0005 & -0.0008 & -0.0008 \\
\hline Milking & 0.0955 & 0.1341 & 0.3223 & & \\
\hline MilkingSq & -0.0048 & -0.0380 & -0.1237 & & \\
\hline System & 0.0441 & 0.0350 & & & \\
\hline FeedPad_Yes & -0.1033 & -0.0503 & & & \\
\hline Brd & 0.0816 & 0.0657 & & & \\
\hline Cow & 0.0001 & & & & \\
\hline EffArea & 0.0009 & & & & \\
\hline Rotary & -0.1988 & & & & \\
\hline Bails & 0.0006 & & & & \\
\hline CowBail & -0.0320 & & & & \\
\hline Cows/ha & 0.0553 & & & & \\
\hline FY_2013/14 & 0.0193 & & & & \\
\hline Weekend & -0.0146 & & & & \\
\hline ESp & 0.1969 & & & & \\
\hline LSp & 0.1410 & & & & \\
\hline Sum & 0.1004 & & & & \\
\hline Aut & 0.0783 & & & & \\
\hline Houses_Yes & -0.1418 & -0.0123 & & & \\
\hline
\end{tabular}

${ }^{1}$ Variable description in Table 2.

The 5 smallest leakage rates averaged $6 \%$ of SDW, suggesting this may be the best achievable rate (i.e., best management practice). However, no other studies have reported water leakage rates on dairy farms to compare with these results. Municipal water systems have been measured to have between 5 to $58 \%$ water leakage and unreported water intakes (Lambert et al., 2002). As well as being an inefficient use of a resource, leakage may temporarily decrease milk production (Cowan et al., 1978; King and Stockdale, 1981) if water intake of cows is restricted. This reduction in milk production may be as great as $20 \%$ if water intake is halved (Steiger Burgos et al., 2001).

Corrected stock drinking water is a more accurate reflection of actual water consumed (i.e., cSDW $=\mathrm{VWI}$ ) than SDW. As SDW is estimated to contain $26 \%$ leakage, and as leakage did not vary with season, cSDW followed the same seasonal pattern as SDW but with lower volumes. The average volume of cSDW reported here $(35 \mathrm{~L} /$ cow per day) is less than that estimated in Ireland $(55 \mathrm{~L} /$ cow per day), the only other long-term study reported (Murphy et al., 2014). However, the volume is similar to the annual SDW volume recorded in the present study, which may suggest that leakage on Irish dairy farms is similar to New Zealand dairy farms. Other shorter, pasture-based studies measured VWI of cows in Australia (15 to $67 \mathrm{~L} /$ cow per day; King and Stockdale, 1981; Stockdale and King, 1983) and SDW $(22,54$, and $41 \mathrm{~L} /$ cow per day; Campbell, 1958; Jago et al., 2005; Morris et al., 2010) in New Zealand. Average VWI in confinement systems from shorter studies were similar or greater than those reported here, with typical values ranging from 50 to $90 \mathrm{~L} /$ cow per day (Murphy et al., 1983; Cardot et al., 2008), and a maximum of $171 \mathrm{~L} /$ cow per day (Meyer et al., 2004). Greater water intakes may be expected in confinement systems as cows receive high-DM feed. In pastoral dairying, cows may ingest 30 to $120 \mathrm{~L} / \mathrm{d}$ of water in feed, which would 
reduce requirements for drinking water. The day-to-day variability in cSDW may be related to the fluctuating DM of pasture, caused by changing soil moisture levels, which results in varied amounts of water ingested through feed.

Repairing leaks may be the single most effective step many pasture-based farmers could take to reduce water use. If the average farm size is 335 cows and a $6 \%$ leakage rate is achievable, the average farm could reduce water use by $1,687,395 \mathrm{~L} /$ farm per year. At a regional level, dairy farm water use could be reduced by 6 billion $\mathrm{L}$. This significant reduction in farm water use would also reduce farm working expenses thorough less electricity use and less maintenance.
Average MPW was $63 \mathrm{~L} /$ cow per day during the main milking period of the year. As might be expected, MPW exhibited a clear seasonal pattern that closely matched milk production; this is likely to also be related to cow numbers, which decrease during the season due to culling and staged dry off. Although MPW was similar between rotary and herringbone parlors, rotary parlors used $8 \mathrm{~L} /$ cow per day more than herringbone parlors in autumn; this difference is consistent with the report of Callinan (2009). The MPW presented in the current study is consistent with MPW of similar milking parlors that have the same cleaning methods (high-pressure hose wash down; Callinan, 2009). In contrast, MPW reported in our study is higher than

Table 5. Partial least squared regression models ${ }^{1}$ and polynomial regression model equations (raw coefficients) for predicting milking parlor water use $\left(\log _{10} \mathrm{MPW}\right)$ on pasture-based dairy farms

\begin{tabular}{|c|c|c|c|c|c|}
\hline Variable $^{1}$ & Model 1 & Model 2 & Model 3 & Model 4 & Model 5 \\
\hline$\overline{\mathrm{R}^{2}}$ & 0.61 & 0.57 & 0.55 & 0.51 & 0.48 \\
\hline$P$-value & $<0.001$ & $<0.001$ & $<0.001$ & $<0.001$ & $<0.001$ \\
\hline Constant & 1.8750 & 1.4659 & 1.1684 & 0.6290 & 0.6290 \\
\hline TMax & 0.0003 & & & & \\
\hline TMaxSq & 0.0002 & & & & \\
\hline TMin & -0.0057 & & & & \\
\hline TMinSq & 0.0003 & & & & \\
\hline Rain & -0.0022 & -0.0028 & & & \\
\hline RainSq & 0.0001 & 0.0001 & & & \\
\hline Evap & 0.0084 & & & & \\
\hline EvapSq & -0.0015 & & & & \\
\hline Wind & 0.0182 & & & & \\
\hline WindSq & -0.0003 & & & & \\
\hline $\operatorname{Rad}$ & 0.0030 & & & & \\
\hline RadSq & -0.0001 & & & & \\
\hline Milk Sol & 0.2639 & 0.4674 & 0.4174 & 0.5318 & \\
\hline Milk SolSq & -0.0236 & -0.1841 & -0.2082 & & \\
\hline Milk Vol & 0.0179 & 0.0187 & 0.0259 & -0.0246 & \\
\hline Milk VolSq & -0.0003 & & & & \\
\hline Milking & 0.2269 & 0.3180 & 0.3152 & 0.4636 & 0.7043 \\
\hline MilkingSq & 0.0294 & -0.0259 & -0.0214 & -0.0561 & -0.0868 \\
\hline System & 0.0286 & -0.0704 & & & \\
\hline FeedPad_Yes & -0.1119 & & & & \\
\hline Brd & -0.4443 & -0.2648 & -0.3012 & & \\
\hline Cow & 0.0000 & & & & \\
\hline EffArea & -0.0001 & & & & \\
\hline Rotary & 0.3388 & 0.0914 & & & \\
\hline Bails & -0.0062 & & & & \\
\hline CowBail & -0.0253 & -0.0387 & -0.0285 & & \\
\hline Cows/ha & -0.1650 & & & & \\
\hline FY_2013/14 & -0.0231 & & & & \\
\hline Weekend & -0.0393 & & & & \\
\hline ESp & -0.0507 & & & & \\
\hline LSp & -0.1091 & & & & \\
\hline Sum & -0.0443 & & & & \\
\hline Aut & 0.0597 & & & & \\
\hline Houses_Yes & 0.2197 & & & & \\
\hline Recycle_Yes & -0.0011 & & & & \\
\hline Recirculate_Yes & -0.2821 & & & & \\
\hline SnapCh_Yes & -0.0742 & & & & \\
\hline RecyRecirSnapC & & 0.0155 & & & \\
\hline
\end{tabular}

${ }^{1}$ Variable description in Table 2. 
Table 6. Partial least squared regression models ${ }^{1}$ and polynomial regression model equations (raw coefficients) for predicting total water use $\left(\log _{10} \mathrm{TW}\right)$ on pasture-based dairy farms

\begin{tabular}{|c|c|c|c|c|}
\hline Variable $^{1}$ & Model 1 & Model 2 & Model 3 & Model 4 \\
\hline$\overline{\mathrm{R}^{2}}$ & 0.49 & 0.46 & 0.43 & 0.41 \\
\hline$P$-value & $<0.001$ & $<0.001$ & $<0.001$ & $<0.001$ \\
\hline Constant & 1.4673 & 1.4995 & 1.1042 & 1.4399 \\
\hline TMax & 0.0104 & 0.0124 & 0.0154 & \\
\hline TMaxSq & 0.0001 & & & \\
\hline TMin & -0.0060 & & & \\
\hline TMinSq & 0.0001 & & & \\
\hline Rain & -0.0020 & & & \\
\hline RainSq & 0.0001 & & & \\
\hline Evap & 0.0172 & & & \\
\hline EvapSq & -0.0046 & -0.0109 & -0.0113 & \\
\hline Wind & 0.0073 & & & \\
\hline WindSq & -0.0011 & & & \\
\hline $\operatorname{Rad}$ & 0.0069 & 0.0208 & 0.0156 & \\
\hline RadSq & -0.0001 & -0.0001 & & \\
\hline Milk Sol & 0.1859 & 0.5446 & 0.4870 & 0.9076 \\
\hline Milk SolSq & -0.0330 & -0.2542 & -0.2653 & -0.3021 \\
\hline Milk Vol & 0.0105 & 0.0175 & 0.0249 & \\
\hline Milk VolSq & -0.0005 & & & \\
\hline Milking & 0.0946 & & & \\
\hline MilkingSq & 0.0014 & & & \\
\hline System & -0.0219 & -0.0321 & & \\
\hline FeedPad_Yes & 0.0323 & 0.0717 & & \\
\hline Brd & 0.0356 & 0.0115 & & \\
\hline Cow & -0.0002 & & & \\
\hline EffArea & -0.0006 & & & \\
\hline Rotary & 0.1571 & 0.1578 & 0.0505 & \\
\hline Bails & 0.0041 & & & \\
\hline CowBail & -0.0153 & -0.0233 & & \\
\hline Cows/ha & -0.0302 & & & \\
\hline FY_2013/14 & -0.0282 & & & \\
\hline Weekend & -0.0173 & & & \\
\hline ESp & 0.2338 & & & \\
\hline LSp & 0.2418 & & & \\
\hline Sum & 0.2141 & & & \\
\hline Aut & 0.2190 & & & \\
\hline Houses_Yes & 0.0392 & 0.0175 & & \\
\hline Recycle_Yes & -0.0765 & & & \\
\hline Recirculate_Yes & -0.0256 & & & \\
\hline SnapCh_Yes & 0.0377 & & & \\
\hline RecyRecirSnapC & & -0.0851 & & \\
\hline
\end{tabular}

${ }^{1}$ Variable description in Table 2 .

smaller parlors of different types that do not use highpressure hose wash down (Gamroth and Moore, 1995; Janni et al., 2009), and is substantially less than MPW in parlors that group wash cows before milking (Meyer et al., 2006).

The model prediction of cSDW that resulted from our study is easier to use on pasture-based dairy farms than other available models. Our models included climate variables to approximate the soil moisture and, therefore, variation in DM of pasture. Water consumed in feed eaten per day could vary by over $90 \mathrm{~L} /$ cow per day between seasons. Existing models, such as those of Cardot et al. (2008), Murphy et al. (1983), and Holter and Urban (1992), have not been created with such a wide range of feed conditions. It is expected that DM and DMI significantly influence cSDW, but these parameters are not easily nor routinely measured on pasture-based farms. Models from intensively managed indoor systems have reported similar or higher coefficient of determination values compared with our cSDW models, and this reflects the level of monitoring of feed that is possible in these systems. The coefficient of determination values of our models are considered to be reasonable given the lack of feed and intake data and the wide range of environmental and feed conditions. Other variables used in the housed system models (Cowan et al., 1978; Khelil-Arfa et al., 2012) were approximated in our models (BW and sunshine hours, with average breed and solar radiation) and included milk yield and maximum temperature, but not such variables as sodium content due to insufficient data. The models we produced were able to predict cSDW 
Table 7. Evaluation of models to predict corrected stock drinking water [cSDW ${ }^{1}$; cSDW model 3, Castle and Thomas (1975), Dahlborn et al. (1998)], milking parlor water (MPW; MPW model 3), and total water (TW; TW model 3)

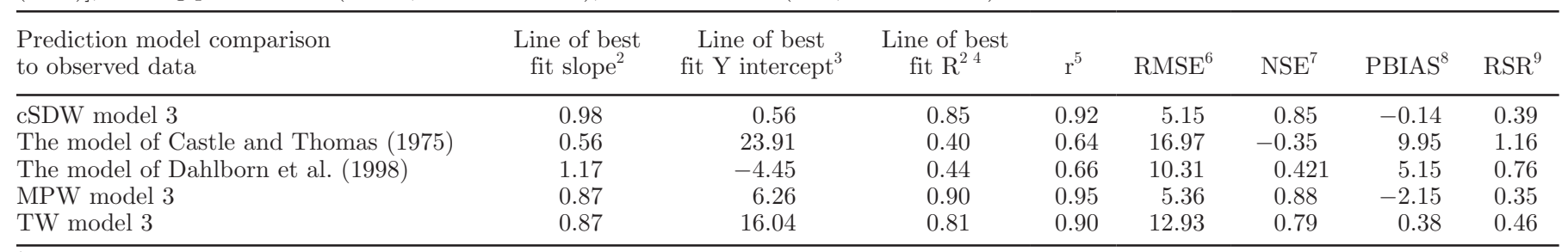

${ }^{1} \mathrm{cSDW}=$ stock drinking water - leakage.

${ }^{2}$ Line of best fit slope (L/cow per day), optimum $=1$.

${ }^{3}$ Line of best fit $\mathrm{Y}$ intercept (L/cow per day), optimum $=0$.

${ }^{4}$ Line of best fit $\mathrm{R}^{2}$, optimum $=1$.

${ }^{5}$ Pearson correlation coefficient, optimum $=1$ or -1 .

${ }^{6} \mathrm{RMSE}=$ root mean square error $(\mathrm{L} / \mathrm{cow}$ per day $)$, optimum $=1$.

${ }^{7} \mathrm{NSE}=$ Nash-Sutcliffe efficiency, optimum $=1,>0$ is acceptable, if $<0$ then the mean is a better predictor than the model.

${ }^{8} \mathrm{PBIAS}=$ percentage bias, optimum $=0$, positive values mean underestimation, and negative means overestimation.

${ }^{9} \mathrm{RSR}=$ RMSE-observations standard deviation ratio, optimum $=0$.

a)

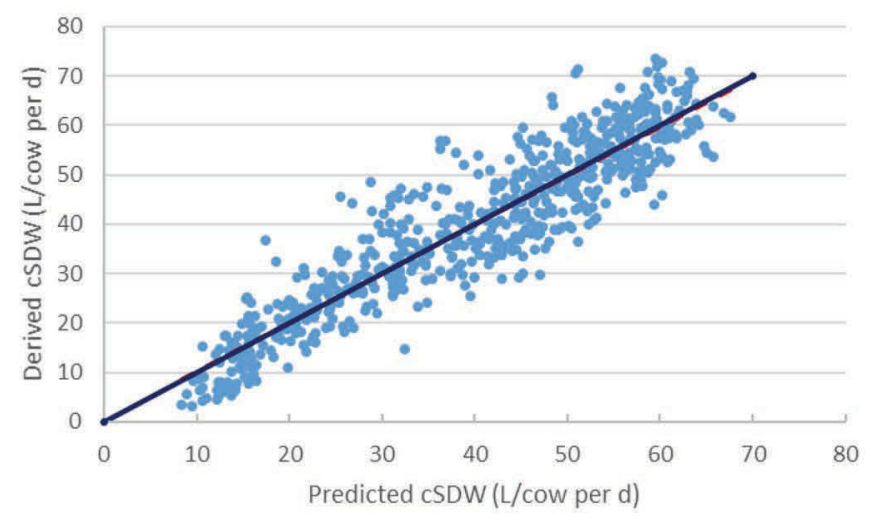

c)

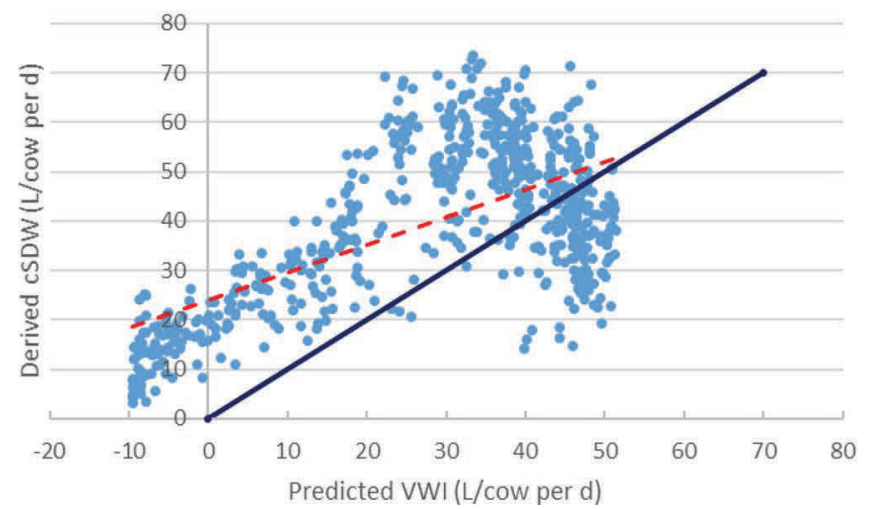

b)

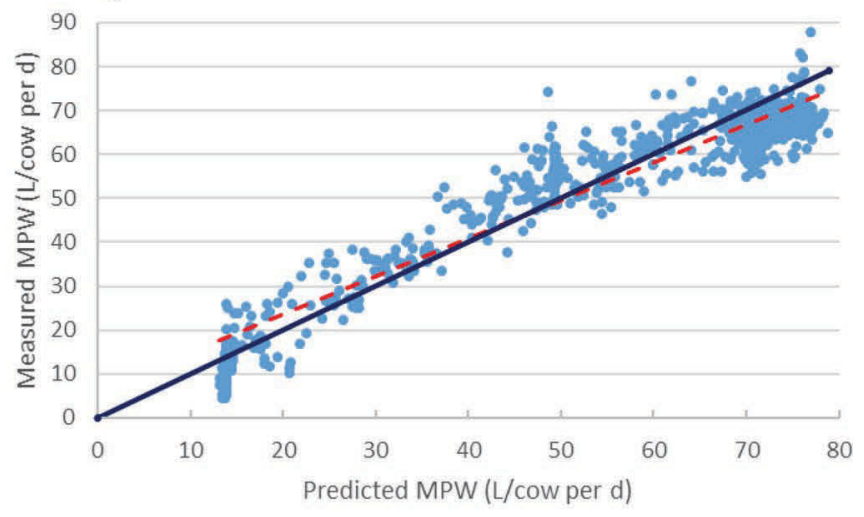

d)

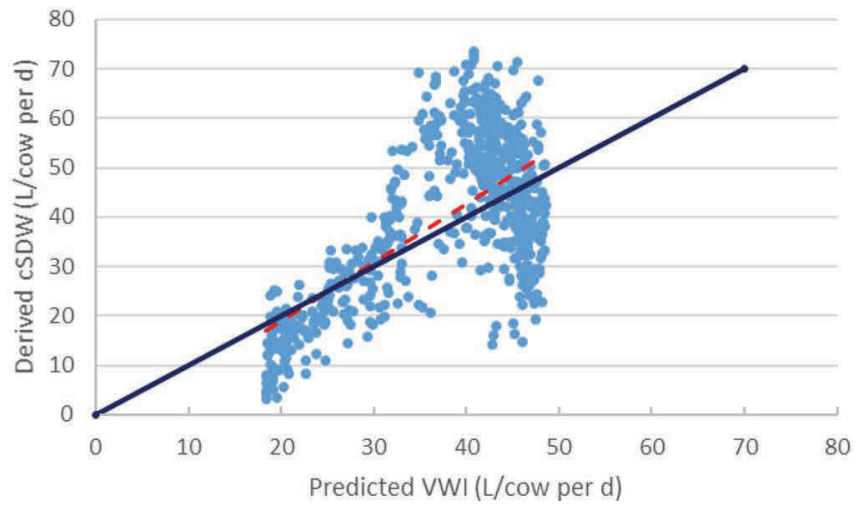

Figure 2. Measured or derived mean water use (number of farms $\geq 5$ ) versus predicted water use (dashed line of best fit) and solid 1:1 line for (a) corrected stock drinking water (cSDW) model $3\left(\mathrm{R}^{2}=0.84\right)$, (b) milking parlor water use (MPW) model $3\left(\mathrm{R}^{2}=0.90\right)$, (c) the model of Castle and Thomas $\left(1975 ; \mathrm{R}^{2}=0.41\right)$, and $(\mathrm{d})$ the model of Dahlborn et al. $\left(1998 ; \mathrm{R}^{2}=0.46\right)$. VWI = voluntary water intake. Color version available online. 
more accurately compared with the existing models of VWI.

We also produced accurate models to predict MPW and TW that are easy to use on pasture-based dairy farms. The initial models that included the most variables had the greatest explanatory power, but the models do not lend themselves to practical use. The models with fewer variables may be more useful for predicting water use, particularly where limited data are available. We were unable to find any other models predicting MPW and TW to compare with our results.

The models produced here will allow increased accuracy of water use to be predicted for farms within a climate region, allowing water to be efficiently allocated. This will aid development of farm infrastructure and water reticulation, and provide benchmark wateruse efficiency values to compare individual farms. The water-use values predicted by the models help identify opportunities to improve water-use efficiency (e.g., reduce leakage) and help track progress on farms that are aiming to improve water-use efficiency. The models may also be useful to predict farm water requirements in response to short- and long-term climate change. The detailed benchmark water-use data will be useful in calculating water footprints, removing the need to rely on lower-accuracy estimates to compare water use between dairy production in different areas. As the models were developed on nonirrigated pasture-based dairy farms, further research is required to evaluate the performance of the models on irrigated pasture-based dairy farms.

\section{CONCLUSIONS}

Annual water use on pasture-based, seasonally calving dairy farms was cyclical in response to climate and milk production variables. Significant opportunities to improve water-use efficiency were identified by reducing the $26 \%$ of reticulated water that was lost as leakage from the system. Models were developed to predict water use using variables accessible to pasture-based farms. Results from these models for cSDW were more accurate than using VWI models developed for confined feeding systems. The models we presented were the first models we could find predicting MPW and TW, and can be used to benchmark progress for improved water-use efficiency.

\section{ACKNOWLEDGMENTS}

The authors wish to acknowledge the farmers involved, and the effort they put in to supply data for this study. This work was supported by funding from
New Zealand dairy farmers through DairyNZ Inc. investment in the Sustainable Dairying: Water Accord (ES1406).

\section{REFERENCES}

Appuhamy, J. A., C. Wagner-Riddle, D. P. Casper, J. France, and E. Kebreab. 2014. Quantifying body water kinetics and fecal and urinary water output from lactating Holstein dairy cows. J. Dairy Sci. 97:6177-6195.

Callinan, L. 2009. Dairy Shed Water Use in Victoria. Department of Primary Industries, Melbourne, Australia.

Campbell, I. L. 1958. Water requirements of dairy cows. Pages 53-60 in Massey Agricultural College Dairyfarming Annual, vol. 1958. Massey Agricultural College, Palmerston North, New Zealand.

Cardot, V., Y. Le Roux, and S. Jurjanz. 2008. Drinking behavior of lactating dairy cows and prediction of their water intake. J. Dairy Sci. 91:2257-2264.

Castle, M. E., and T. P. Thomas. 1975. Water-intake of British Friesian cows on rations containing various forages. Anim. Prod. 20:181-189.

Cheung, P. B., G. V. Girol, N. Abe, and M. Propato. 2010. Night flow analysis and modeling for leakage estimation in a water distribution system. Pages 509-513 Integrating Water Systems. CRC Press-Taylor \& Francis Group, Boca Raton, FL.

Cichota, R., V. O. Snow, and A. B. Tait. 2008. A functional evaluation of virtual climate station rainfall data. N. Z. J. Agric. Res. 51:317-329.

Cowan, R. T., D. Shackel, and T. M. Davison. 1978. Water intakes, milk-yield and grazing behaviour of Friesian cows with restricted access to water in a tropical upland environment. Aust. J. Exp. Agric. 18:190-195.

Dahlborn, K., M. Akerlind, and G. Gustafson. 1998. Water intake by dairy cows selected for high or low milk-fat percentage when fed two forage to concentrate ratios with hay or silage. Swed. J. Agric. Res. 28:167-176.

DairyNZ. 2012. Facts and Figures for New Zealand Dairy Farmers. DairyNZ, Hamilton, New Zealand.

Food and Agriculture Organization. 2009. Global Agriculture Towards 2050. A. D. E. Division, ed. Food and Agriculture Organization of the United Nations, Rome, Italy.

Gamroth, M. J., and J. A. Moore. 1995. Water use on Oregon dairy farms. Vol. 95. Seventh International Symposium on Agricultural and Food Processing Wastes. No. 7. ASAE, Chicago, IL.

Holter, J. B., and W. E. Urban. 1992. Water partitioning and intake prediction in dry and lactating holstein cows. J. Dairy Sci. 75:1472-1479.

International Water Management Institute. 2007. Water for Food, Water for life. A Comprehensive Assessment of Water Management in Agriculture. Earthscan, London, UK.

Jago, J. G., J. R. Roche, E. S. Kolver, and M. W. Woolford. 2005. The drinking behaviour of dairy cows in late lactation. Pages 209-214 in Proc. NZ. Soc. Anim. Prod., vol. 65. N. Z. Soc. Anim. Prod., Christchurch, New Zealand.

Janni, K. A., S. H. Christopherson, and D. R. Schmidt. 2009. Milk house wastewater flows and characteristics for small dairy operations. Appl. Eng. Agric. 25:417-423.

Khelil-Arfa, H., A. Boudon, G. Maxin, and P. Faverdin. 2012. Prediction of water intake and excretion flows in Holstein dairy cows under thermoneutral conditions. Animal 6:1662-1676.

King, K. R., and C. R. Stockdale. 1981. Milk-yield of dairy-cows given restricted access to water in a mediterranean-type climate. Aust. J. Exp. Agric. 21:167-171.

Kmoch, A., H. Klug, A. B. H. Ritchie, J. Schmidt, and P. A. White. 2015. A spatial data infrastructure approach for the characterization of new zealand's groundwater systems. Trans. GIS 20:626641. https://doi.org/10.1111/tgis.12171.

Kume, S., K. Nonaka, T. Oshita, and T. Kozakai. 2010. Evaluation of drinking water intake, feed water intake and total water intake in dry and lactating cows fed silages. Livest. Sci. 128:46-51. 
Lambert, A. O., F. Mendaza, O. A. Tveit, N. A. Z. Abdin, L. Lazzari, H. Lorenze, H. Lee, M. Farley, E. Masakat, R. Suphani, H. Esko, K. Johnson, M. Rapinat, P. Dohnal, R. McKenzie, A. Manesc, D. Weimer, S. K. S. Lai, E. Somos, A. Monteir, S. Davis, F. Martinez, and S. L. Lo. 2002. International report: Water losses management and techniques. Pages 1-20 in 2nd World Water Congress: Water Distribution and Water Services Management. Vol. 2. P. Wilderer, G. Amy, E. Arvin, L. Blackwell, M. F. Hamoda, P. S. Mikkelsen, T. Mino, E. Morgenroth, R. Otterpohl, M. N. Pons, W. Rauch, T. Stephenson, Z. Ujang, and Z. Jianrong, ed. IWA Publishing, London, UK.

Little, W., and S. R. Shaw. 1978. A note on the individuality of intake of drinking water by dairy cows. Anim. Sci. 26:225-227.

Meyer, D., B. Reed, C. Batchelder, I. Zallo, P. L. Ristow, G. Higginbotham, M. Arana, T. Shultz, D. D. Mullinax, and J. Merriam. 2006. Water use and winter liquid storage needs at central valley dairy farms in California. Appl. Eng. Agric. 22:121-126.

Meyer, U., M. Everinghoff, D. Gadeken, and G. Flachowsky. 2004 Investigations on the water intake of lactating dairy cows. Livest. Prod. Sci. 90:117-121.

Ministry of Health. 2006. Household Water Supplies. Ministry of Health, Wellington, New Zealand.

Moriasi, D. N., J. G. Arnold, M. W. Van Liew, R. L. Bingner, R. D. Harmel, and T. L. Veith. 2007. Model evaluation guidelines for systematic quantification of accuracy in watershed simulations. Trans. ASABE 50:885-900.

Morris, C. A., S. M. Hickey, E. R. Thom, and C. D. Waugh. 2010 Daily water intake by individual dairy cows on a pasture diet during mid lactation. Pages 257-260 in Proc. NZ. Soc. Anim. Prod., vol. 70. N. Z. Soc. Anim. Prod., Palmerston North, New Zealand.

Murphy, E., T. Curran, J. Humphreys, and J. Upton. 2014. Direct water use of Irish dairy farms. Page 47 in Proc. Agric. Res. Forum. Agricultural Research Forum, Tullamore, Ireland.

Murphy, M. R., C. L. Davis, and G. C. McCoy. 1983. Factors affecting water-consumption by Holstein cows in early lactation. J. Dairy Sci. 66:35-38.

R Core Team. 2015. R: A Language and Environment for Statistical Computing. R Foundation for Statistical Computing, Vienna, Austria.

Ramsbottom, G., B. Horan, D. P. Berry, and J. R. Roche. 2015. Factors associated with the financial performance of spring-calving, pasture-based dairy farms. J. Dairy Sci. 98:3526-3540.
Ridoutt, B. G., and S. Pfister. 2010. A revised approach to water footprinting to make transparent the impacts of consumption and production on global freshwater scarcity. Glob. Environ. Change $20: 113-120$.

Roche, J. R., A. W. Bell, T. R. Overton, and J. J. Loor. 2013. Nutritional management of the transition cow in the 21st century-A paradigm shift in thinking. Anim. Prod. Sci. 53:1000-1023.

Scarsbrook, M. R., and A. R. Melland. 2015. Dairying and waterquality issues in Australia and New Zealand. Anim. Prod. Sci. $55: 856-868$.

Sobek, S., L. J. Tranvik, and J. J. Cole. 2005. Temperature independence of carbon dioxide supersaturation in global lakes. Glob. Biogeochem. Cycles 19:GB2003. https://doi.org/10.1029/2004GB002264.

Steiger Burgos, M., M. Senn, F. Sutter, M. Kreuzer, and W. Langhans. 2001. Effect of water restriction on feeding and metabolism in dairy cows. Am. J. Physiol. Regul. Integr. Comp. Physiol. 280:R418-R427.

Stockdale, C. R., and K. R. King. 1983. A note on some of the factors that affect the water-consumption of lactating dairy-cows at pasture. Anim. Prod. 36:303-306.

Tabesh, M., A. H. A. Yekta, and R. Burrows. 2009. An integrated model to evaluate losses in water distribution systems. Water Resour. Manage. 23:477-492.

United Nations. 2015. World Population Prospects: The 2015 Revision, Key Findings and Advance Tables. Department of Economic and Social Affairs, Population Division, United Nations, New York, NY.

Wani, S. P., J. Rockstrom, and T. Oweis. 2009. Rainfed Agriculture: Unlocking the Potential. CABI, Wallingford, UK.

Wold, S., M. Sjöström, and L. Eriksson. 2001. PLS-regression: A basic tool of chemometrics. Chemom. Intell. Lab. Syst. 58:109-130.

World Water Assessment Programme. 2009. The United Nations World Water Development Report 3: Water in a Changing World. UNESCO, Paris, France; Earthscan, London, UK.

Zonderland-Thomassen, M. A., and S. F. Ledgard. 2012. Water footprinting - A comparison of methods using New Zealand dairy farming as a case study. Agric. Syst. 110:30-40. 